ISSN 1392-3196 / e-ISSN 2335-8947

Zemdirbyste-Agriculture, vol. 100, No. 4 (2013), p. 363-368

DOI 10.13080/z-a.2013.100.046

\title{
The influence of pasturable and stall period diets of dairy cows on the electrical conductivity of milk
}

\author{
Aurimas BRAZAUSKAS, Arūnas JUOZAITIS, Rolandas STANKEVIČIUS, \\ Vida JUOZAITIENĖ, Vytuolis ŽILAITIS \\ Veterinary Academy, Lithuanian University of Health Sciences \\ Tilžès 18, Kaunas, Lithuania \\ E-mail: aurimas.brazauskas@gmail.com
}

\begin{abstract}
The aim of this study was to analyse the influence of dairy cows' diet on electrical conductivity (EC) of milk during pasturable and stall periods and to assess EC relationship with milk yield and somatic cell count (SCC). The experiments were carried out during 2009-2013 with 421 dairy cows which were milked using an automated voluntary milking system "DeLaval VMS" ("DeLaval", Sweden). All year round the cows were kept untied indoors and fed on farm-made grass silage forage, during pasturable period the diet was supplemented with a fresh legume/ grass mixture. The data consisted of 462582 milking records. The average EC of milk $\left(4.92 \pm 0.001 \mathrm{mS} \mathrm{cm}^{-1}\right) \mathrm{met}^{-1}$ zootechnical standards. The average milk yield was $25.12 \pm 0.020 \mathrm{~kg}$, milk SCC $-188.95 \pm 1.032$ thousand $\mathrm{ml}^{-1}$. Milk yield during pasturable period was in average 1.4\% lower and SCC was $7.9 \%$ higher than during the stall period. The average EC during pasturable period of the experiment was 3.6\% higher than during the stall period in all lactations $(p<0.001)$. The higher $(23.03 \mathrm{~g})$ cows' ruminal N-balance (RNB) during pasturable period had no positive effect on milk yield as SCC increased during that period. The correlation between milk yield and $\mathrm{EC}$ of milk during pasturable and stall periods was negative $(r=-0.124-0.226, p<0.001)$. The observed SCC was lower than 200 thousand $\mathrm{ml}^{-1}$ in the milk samples where EC was in the range of 4.6 to $5.8 \mathrm{mS} \mathrm{cm}^{-1}$. As EC increased, SCC had a statistically significant $(p<0.001)$ rise both in pasturable and stall periods $(r=0.356-0.403)$. EC of milk could provide an alternative way for early diagnosis of mastitis.
\end{abstract}

Key words: correlation, forage, milk yield, somatic cell count.

\section{Introduction}

Milk production is one of the most complicated agricultural industries. The main factors governing the cost-effectiveness of milk production are the genetic potential of livestock, feed and nutrition, and animal keeping technologies (Juozaitienè, Žakas, 2002; Moussaoui et al., 2004). Milk production and quality of milk are greatly influenced by the diet and feeding techniques. These factors account for approximately 50 $60 \%$ of the dairy farm costs (Mockevičienè et al., 2008).

Bovine mastitis remains as the disease causing the biggest economic losses to the dairy industry (Seegers et al., 2003; Moussaoui et al., 2004). De Mol and Ouweltjes (2001) indicated that early detection of mastitis is very important, not only because of the economic impact due to yield losses, but also because of the negative effects on the animals' welfare. Some authors state that somatic cell count (SCC), which is widely regarded as mastitis indicator, depends on time of the year (Riekerink et al., 2007; Kondrotaite et al., 2013). Riekerink et al. (2007) indicate that the highest SCC is observed in late summer and early autumn. Green et al. (2006) state that the increase of SCC in the early summer months is influenced by the cows with subclinical mastitis. The immune system of cows after the winter season is very low and with the start of pasturable season and increased productivity the incidence of mastitis starts to grow (Klimienè et al., 2005). The seasonal fluctuation of SCC is caused by seasonal mastitis, overheat, cold and contusion of the udder tissue (Juozaitiene, Žakas, 2002), thus cows require properly balanced diets during this time of the year. Nutrition can influence the cow's resistance to mastitis. The major impact of nutrition on udder health is via suppression of the immune system.

Electrical conductivity (EC) of milk was introduced as an indicator of mastitis several decades ago. Until now EC has solely been used for detection of bovine mastitis on the phenotypic level. However, EC may be used as an indicator of mastitis in a breeding program where selection against mastitis is included. SCC has been widely considered to be the most useful indirect measure of mastitis. However, using SCC for genetic evaluation has some disadvantages such as low recording frequency. Most automatic milking systems are equipped with sensors for measuring EC, and EC can be easily recorded at every milking. Genetic correlations between EC and mastitis have been estimated to be in the 
range from 0.65 to 0.8 , hence, obtaining genetic response for mastitis should be possible by using information of EC in genetic evaluation. However, collecting and implementing EC information in a breeding program may be a challenge (Norberg, 2005).

Modern automatic milking systems can register EC data relatively cheaply and rapidly. Musser et al. (1998) state that absolute and differential EC scores for cows with subclinical mastitis are significantly higher than those for healthy cows, and absolute EC score is significantly associated with detection of the disease. Various studies show positive correlation between EC and SCC, which can be used as mastitis indicators (Musser et al., 1998; Norberg, 2005). Modern dairy farms use these indicators for electronic udder health status control. Milk SCC and EC were associated with daily production loss; the effects were additive. Therefore, EC and SCC can be utilized as indirect tests of subclinical mastitis (Nielen et al., 1993).

The aim of this experiment was to investigate the potential influence of cows' diets during pasturable and stall periods on EC of milk, milk yield and SCC in dairy herds and to analyse the relationship among these traits.

\section{Materials and methods}

The study was carried out during 2009-2013 at Veterinary Academy of Lithuanian University of Health Sciences, state owned company Agriculture Information and Rural Business Centre and three high production milk farms in Lithuania. Data from a total of 421 dairy cows which were milked using automated voluntary milking system "DeLaval VMS" ("DeLaval", Sweden) were collected for the period from June 2008 to November 2011. The data consisted of milk yield, electrical conductivity (EC) of milk and somatic cell count (SCC), a total of 462582 milking records were evaluated and analysed.

All year round the test cows were kept untied indoors and fed on farm-made grass silage forage. Periods taken into consideration in the study are pasturable period (from $15^{\text {th }}$ May till $15^{\text {th }}$ October) and stall period (from $15^{\text {th }}$ October till $15^{\text {th }}$ May). The combined feed had identical nutritional and energy values during pasturable and stall periods. During pasturable period the diet was supplemented with a fresh legume/grass mixture. The diets were optimised using computer feed consultancy programme HYBRIMIN Futter 2008. The feed intake was controlled by weighing the feed given to the cows in the automated milking system. RNB was calculated using the formula (Weiss et al., 2005):

$\mathrm{RNB}=(\mathrm{CP}-\mathrm{uCP}): 6.25$, where $\mathrm{RNB}$ is ruminal N-balance, $\mathrm{CP}$ - crude protein, $\mathrm{uCP}$ - usable crude protein.

Statistical analysis. The data of milk yield, EC of milk and SCC were processed using MS SQL Server 2005 database management system and $R$ statistical package (http://www.r-project.org) was used for statistical analysis. Arithmetical averages $(\bar{X})$, standard errors $( \pm m \bar{X})$, average square deviation (SD) and coefficients of variation (CV) were calculated. The data of SCC were log transformed to base 10. This logarithmic transformation achieved normality of distribution.

\section{Results}

The average composition of cows' diet is displayed in Table 1. Both during pasturable and stall periods the test cows were fed diets that contained $18.6 \mathrm{~kg}$ dry matter, net energy of lactation was almost identical (stall period diet had 1.44 MJ more energy). During pasturable period the diet was enriched by adding a fresh legume/grass mixture. According to results of our research, the diet during pasturable period had $159 \mathrm{~g}$ more crude protein, as well as usable crude protein $0.56 \%$ more than during stall period. The comparison of diet composition also shows that RNB was higher by $23.03 \mathrm{~g}$ in the diet of pasturable period in comparison with the stall period diet.

Table 1. Dairy cows' diets in pasturable $\left(15^{\text {th }}\right.$ May $-15^{\text {th }}$ October $)$ and stall $\left(15^{\text {th }}\right.$ October $-15^{\text {th }}$ May $)$ periods and their differences

\begin{tabular}{|c|c|c|c|c|c|}
\hline \multirow[t]{2}{*}{ Diet } & \multirow[t]{2}{*}{ Unit } & \multirow[t]{2}{*}{ Pasturable period } & \multirow[t]{2}{*}{ Stall period } & \multicolumn{2}{|c|}{$\begin{array}{l}\text { Difference between diets in pasturable } \\
\text { and stall periods }\end{array}$} \\
\hline & & & & unit & $\%$ \\
\hline Haylage & $\mathrm{kg}$ & 17 & 20 & -3 & -15 \\
\hline Corn silage & $\mathrm{kg}$ & 10 & 15 & -5 & -33.33 \\
\hline Combined feed & $\mathrm{kg}$ & 9 & 8.56 & 0.44 & 5.14 \\
\hline Mineral supplement & $\mathrm{kg}$ & 0.007 & 0.01 & -0.003 & -30 \\
\hline Grass & $\mathrm{kg}$ & 10 & 0 & 10 & - \\
\hline \multicolumn{6}{|l|}{ Composition of the diet: } \\
\hline dry matter & $\mathrm{kg}$ & 18.6 & 18.6 & 0 & 0 \\
\hline net energy of lactation & $\mathrm{MJ}$ & 116.16 & 117.6 & -1.44 & -1.22 \\
\hline crude protein & $\mathrm{g}$ & 3025 & 2866 & 159 & 5.55 \\
\hline crude fiber & $\mathrm{kg}$ & 3.81 & 3.78 & 0.03 & 0.79 \\
\hline usable crude protein & $\mathrm{g}$ & 2713 & 2698 & 15 & 0.56 \\
\hline Ruminal N-balance & $g$ & 50.02 & 26.99 & 23.03 & 85.33 \\
\hline calcium & $\mathrm{g}$ & 137.94 & 131.37 & 6.57 & 5 \\
\hline phosphorus & $\mathrm{g}$ & 72.5 & 69.92 & 2.58 & 3.69 \\
\hline calcium:phosphorus & ratio & $1.90: 1$ & $1.88: 1$ & $0.02: 1$ & 1.06 \\
\hline
\end{tabular}


The composition of diets during pasturable and stall periods is displayed in Figure. During stall period the haylage accounted for $45.9 \%$ of the diet, which was $8.94 \%$ more than during pasturable period. Stall period diet also had more corn silage $-34.43 \%$ of the whole diet compared to $21.73 \%$ of the diet during pasturable period $(12.7 \%$ less $)$. The amount of combined feed was similar both during pasturable and stall periods, and accounted for $19.56 \%$ and $19.65 \%$ of the diets, respectively. The cows were fed fresh grass only during pasturable period and it accounted for $21.73 \%$ of the diet. The diet of stall period contained $3.78 \mathrm{~kg}$ of crude fiber, $2.488 \mathrm{~kg}$ of structural fiber, neutral detergent fiber (NDF) made up $31.92 \%$ of dry matter (DM), acid detergent fiber (ADF) - $18.31 \%$ of DM. Pasturable period diet had a slightly higher content of crude fiber $-3.81 \mathrm{~kg}$, structural fiber was almost identical $-2.39 \mathrm{~kg}$. NDF and ADF content in DM was by 4.92 and $3.31 \%$ lower, respectively than during pasturable period.

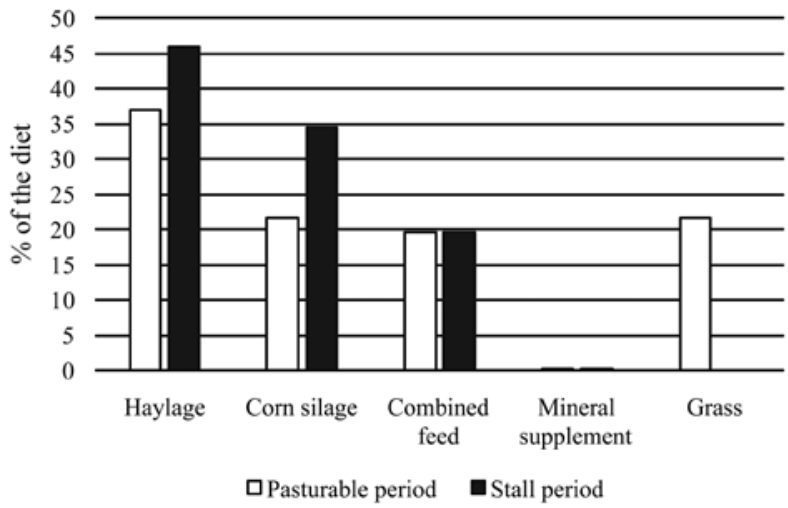

Figure. Composition of dairy cow diets during pasturable $\left(15^{\text {th }}\right.$ May $-15^{\text {th }}$ October $)$ and stall $\left(15^{\text {th }}\right.$ October $-15^{\text {th }}$ May) periods

Analysis of milking system data showed that the average EC of milk $\left(4.92 \pm 0.001 \mathrm{mS} \mathrm{cm}^{-1}\right)$ and variation $(13.02 \%)$ for the total period of our study met zootechnical standards. The data of milk EC for each month of year are displayed in Table 2. As the data in the table suggest the highest EC ranging from 5.03 to $5.11 \mathrm{mS} \mathrm{cm}{ }^{-1}$ was recorded in the summer months, while the lowest EC from 4.73 to $4.81 \mathrm{mS} \mathrm{cm}^{-1}$ was recorded in the winter months. All the results when compared to preceding months were statistically significant $(p<0.001)$ with the variation coefficients ranging from 11.98 to 13.81 .

According to Table 3, during the pasturable period EC of milk was by $0.18 \mathrm{mS} \mathrm{cm}^{-1}$ higher than during the stall period $(p<0.001)$. The average EC of milk during both periods met zootechnical standards and variation was similar.

When analysed by lactation number during pasturable and stall periods (Table 4), the average EC of milk showed similar trend. During pasturable period all the lactations recorded higher EC values than during stall period, ranging from $0.01 \mathrm{mS} \mathrm{cm} \mathrm{cm}^{-1}$ in the third lactation cows' milk to $0.29 \mathrm{mS} \mathrm{cm}^{-1}$ in first lactation $(p<0.001)$. With increasing number of lactations EC of milk showed an upward trend rising from 4.91 to $5.40 \mathrm{mS} \mathrm{cm}^{-1}(9.98 \%)$ in pasturable period and from 4.91 to $5.40 \mathrm{mS} \mathrm{cm}^{-1}$ $(15.58 \%)$ in stall period.
Table 2. Electrical conductivity (EC) data for each month of year (average data for June 2008 - November 2013)

\begin{tabular}{lccccc}
\hline \multirow{2}{*}{ Month } & \multicolumn{5}{c}{ EC of milk, mS cm ${ }^{-1}$} \\
\cline { 2 - 6 } & $\mathrm{n}$ & $\bar{X}$ & $\pm m \bar{X}$ & $\mathrm{SD}$ & $\mathrm{CV}$ \\
\hline January & 36150 & $4.73^{* * *}$ & 0.003 & 0.63 & 13.25 \\
February & 34104 & $4.81^{* * *}$ & 0.003 & 0.62 & 12.86 \\
March & 40055 & $4.84^{* * *}$ & 0.003 & 0.62 & 12.89 \\
April & 38862 & $4.90^{* * *}$ & 0.003 & 0.63 & 12.88 \\
May & 41016 & $5.02^{* * *}$ & 0.003 & 0.63 & 12.53 \\
June & 37092 & $5.05^{* * *}$ & 0.003 & 0.63 & 12.52 \\
July & 38614 & $5.11^{* * *}$ & 0.003 & 0.61 & 11.98 \\
August & 40582 & $5.03 * * *$ & 0.003 & 0.69 & 13.81 \\
September & 39079 & $4.98^{* * *}$ & 0.003 & 0.64 & 12.83 \\
October & 41787 & $4.85^{* * *}$ & 0.003 & 0.65 & 13.40 \\
November & 39208 & $4.91^{* * *}$ & 0.003 & 0.59 & 12.06 \\
December & 36025 & $4.79 * * *$ & 0.003 & 0.61 & 12.67 \\
\hline Total / mean & 462574 & 4.92 & 0.001 & 0.64 & 13.02 \\
\hline Note. n- nnyyyyy
\end{tabular}

Note. $\mathrm{n}$ - number of records evaluated, $\bar{X}$ - arithmetical average, $\pm m \bar{X}$ - standard error, $\mathrm{SD}$ - average square deviation, $\mathrm{CV}-$ coefficient of variation; $* * *$ - differences are statistically significant at $p<0.001$ as compared to the preceding month.

Table 3. Electrical conductivity (EC) of milk during pasturable $\left(15^{\text {th }}\right.$ May $-15^{\text {th }}$ October $)$ and stall $\left(15^{\text {th }}\right.$ October $-15^{\text {th }}$ May) periods (average data for June 2008 - November 2013)

\begin{tabular}{lccccc}
\hline \multirow{2}{*}{ Period } & \multicolumn{5}{c}{ EC of milk, $\mathrm{mS} \mathrm{cm}^{-1}$} \\
\cline { 2 - 6 } & $\mathrm{n}$ & $\bar{X}$ & $\pm m \bar{X}$ & $\mathrm{SD}$ & $\mathrm{CV}$ \\
\hline Pasturable period & 238170 & 5.01 & 0.001 & 0.65 & 12.97 \\
Stall period & 224404 & $4.83^{* * *}$ & 0.001 & 0.62 & 12.83 \\
\hline
\end{tabular}

Explanations under Table 2; *** - differences are statistically significant at $p<0.001$ as compared to the pasturable period

Table 4. Electrical conductivity (EC) data during pasturable $\left(15^{\text {th }}\right.$ May $-15^{\text {th }}$ October $)$ and stall $\left(15^{\text {th }}\right.$ October $-15^{\text {th }}$ May) periods by lactation number (average data for June 2008 - November 2013)

\begin{tabular}{lccccc}
\hline \multirow{6}{*}{ Period } & $\mathrm{n}$ & $\bar{X}$ & $\pm m \bar{X}$ & $\mathrm{SD}$ & $\mathrm{CV}$ \\
\cline { 2 - 6 } & \multicolumn{6}{c}{$1^{\text {st }}$ lactation } \\
\hline Pasturable period & 94349 & 4.91 & 0.002 & 0.59 & 12.09 \\
Stall period & 105802 & $4.62^{* * *}$ & 0.002 & 0.54 & 11.60 \\
\hline \multicolumn{6}{c}{$2^{\text {nd }}$ lactation } \\
\hline Pasturable period & 72713 & 5.00 & 0.002 & 0.62 & 12.49 \\
Stall period & 62529 & $4.92^{* * *}$ & 0.002 & 0.60 & 12.11 \\
\hline \multicolumn{7}{c}{$3^{\text {rd }}$ lactation } \\
\hline Pasturable period & 27962 & 5.20 & 0.004 & 0.73 & 13.97 \\
Stall period & 20269 & $5.19^{* * *}$ & 0.005 & 0.67 & 12.92 \\
\hline \multicolumn{7}{c}{$4^{\text {th }}$ and subsequent lactations } \\
\hline Pasturable period & 23098 & 5.40 & 0.004 & 0.65 & 11.94 \\
Stall period & 22062 & $5.34 * * *$ & 0.004 & 0.53 & 9.86 \\
\hline
\end{tabular}

Explanations under Table 2 
Analysis of the dairy cows' diets shows that both during pasturable and stall periods their composition was balanced according to nutrient levels. Diets also met the dairy cow nutrition physiological rates by crude and structural fiber content. Average milk yield in all three dairy farms during the experiment was $25.12 \pm$ $0.020 \mathrm{~kg} \mathrm{day}^{-1}, \mathrm{SCC}$ averaged at $188.95 \pm 1.032$ thousand $\mathrm{ml}^{-1}$. As the data in Table 5 show, averge milk yield during pasturable period was $1.4 \%$ lower than during stall period $(p<0.001)$. Average milk SCC during pasturable period was $7.9 \%$ higher than that of stall period $(p<0.001)$. The correlation between milk yield and EC of milk was slightly negative, $r=-0.124$ and $r=-0.226$ during pasturable and stall periods, respectively; however, the correlation was highly significant $(p<0.001)$. During stall period the correlation between those parameters was 1.8 times stronger in comparison with pasturable period. When evaluated over the total period of this study, the correlation between these parameters was also statistically significant negative $(r=-0.168, p<0.001)$.

Table 5. Milk yield, somatic cell count (SCC) and their correlation with electrical conductivity (EC) of milk during pasturable $\left(15^{\text {th }}\right.$ May $-15^{\text {th }}$ October $)$ and stall $\left(15^{\text {th }}\right.$ October $-15^{\text {th }}$ May) periods (average data for June 2008 - November 2013)

\begin{tabular}{lcccc}
\hline \multirow{2}{*}{ Period } & \multicolumn{3}{c}{ Milk yield, $\mathrm{kg} \mathrm{day}^{-1}$} & \multicolumn{2}{c}{ SCC, thousand $\mathrm{ml}^{-1}$} \\
\cline { 2 - 5 } & $\bar{X}$ & $\pm m \bar{X}$ & $\bar{X}$ & $\pm m \bar{X}$ \\
\hline Pasturable period & 24.92 & 0.028 & 196.56 & 1.531 \\
Stall period & $25.28^{* * *}$ & 0.029 & $183.12^{* * *}$ & 1.266 \\
$\quad$ Average & 25.12 & 0.020 & 188.95 & 1.032 \\
\hline
\end{tabular}

\begin{tabular}{lll}
\hline \multicolumn{3}{c}{ Correlation coefficients with EC } \\
\hline Pasturable period & $-0.124 * * *$ & $0.356^{* * *}$ \\
Stall period & $-0.226^{* * *}$ & $0.403^{* * *}$ \\
Total study period & $-0.168^{* * *}$ & $0.379 * * *$ \\
\hline
\end{tabular}

Explanations under Table 2

Our study results show that SCC did not exceed 200 thousand $\mathrm{ml}^{-1}$ in milk samples where EC was in the range from 4.6 to $5.8 \mathrm{mS} \mathrm{cm}^{-1}$. The correlation coefficient between EC and SCC had similar values both during pasturable and stall periods, 0.356 and $0.403(p<0.001)$ respectively, the relationship being slightly higher during the stall period. When evaluated over the whole study period, with the increase of EC of milk, SCC also had a statistically significant rise $(r=0.379, p<0.001)$.

\section{Discussion}

Our experiment, carried out in three milk farms around Lithuania, shows that both during pasturable and stall periods cows were fed balanced diets, but the pasturable period diet contained $5.55 \%$ more crude protein and $0.56 \%$ more usable crude protein. In addition, RNB was $85.33 \%$ higher during pasturable period. Diets also met the dairy cow nutrition physiological rates by crude and structural fiber content.
Microbes in the cow's rumen break down rumen degradable protein and non-protein nitrogen into amino acids and ammonia to build more microbial protein. However in high production milk farms, due to deficient or excess nitrogen, rumen microbes are unable to produce enough amino acids to meet the cow's productivity. Therefore, maintaining a healthy RNB is essential for keeping the rumen functioning efficiently (Weiss et al., 2005). Proportionate RNB setting ensures that no shortage of nitrogen is experienced in the rumen (von Lengerken, 2004). When composing diets, RNB setting should be positive (above zero). The best setting for better milk yields is when RNB is in the rage of 20-50 g, otherwise crude proteins tend to lose their "efficiency". Positive RNB setting has a positive impact on the synthesis of rumen microbial proteins and overall fermentation processes in the rumen. However, nitrogen overload should also be avoided, because it undermines the quality of milk, harms animals and pollutes the environment (Mikulionienè, Stankevičius, 2002). In our study during the pasturable and stall periods, corn silage accounted for $21.7 \%$ and $34.4 \%$ of the diet, respectively. It was shown that microbial inoculants can have a positive effect on silage characteristics in terms of lower ammonia-N concentrations and reduced dry matter losses (Jatkauskas, Vrotniakienè, 2011). Negative RNB balance is an indicator that the ratio of digestible to non digestible proteins should be adjusted in the diet. When cows are fed grass silage and cereal flour in winter and fresh grass and the same concentrates in summer, the common problem is the excess of digestible protein. In Lithuania, the main protein components in combined forage are soybean, canola or sunflower wholegrain and squeeze. Their crude protein digestibility is $70-80 \%$, and the usage of low digestibility protein is not economically efficient, their thermal or chemical processing lowers the assimilation of amino acids in the rumen (Juozaitiene et al., 2004).

In our study we found that the average EC of milk $\left(4.92 \pm 0.001 \mathrm{mS} \mathrm{cm}^{-1}\right)$ was consistent with that reported by other authors. Hamann and Zecconi (1998) presented values between 4.0 to $5.5 \mathrm{mS} \mathrm{cm}^{-1}$ for healthy and 5.0 and $9.0 \mathrm{mS} \mathrm{cm}^{-1}$ for clinically infected cows from several experiments. Juozaitiene et al. (2010) found that the average EC of milk from Lithuanian Black cow population was $6.30 \pm 0.09 \mathrm{mS} \mathrm{cm}^{-1}$. Norberg et al. (2004) state that the average EC of Danish cattle milk ranged from 5.5 to $6.5 \mathrm{mS} \mathrm{cm}^{-1}$. Average $\mathrm{EC}$ from healthy udder quarters was $4.87 \mathrm{mS} \mathrm{cm}^{-1}$, cows diagnosed with subclinical and clinical forms of mastitis showed EC of 5.37 and 6.44 $\mathrm{mS} \mathrm{cm} \mathrm{c}^{-1}$, respectively. Other authors (Hillerton, Walton, 1991; Hamann, Gyodi, 2000) indicate that milk EC from healthy cows ranges from 4.0 to $5.5 \mathrm{mS} \mathrm{cm}^{-1}$. If EC rises above $6.0 \mathrm{mS} \mathrm{cm}^{-1}$, pathological processes in the udder tissue can be suspected. pakauskas et al. (2006) suggest that EC of milk in the samples taken from healthy cows was $4.3-5.7 \mathrm{mS} \mathrm{cm}^{-1}$, while that of milk taken from cows with subclinical mastitis was $6.1-8.5 \mathrm{mS} \mathrm{cm}^{-1}$ and SCC increased from 500 to 1500 thousand $\mathrm{ml}^{-1}$. When evaluated over the total period of our study, EC of milk 
had a statistically significant correlation with milk SCC $(r=0.379, p<0.001)$. The high correlation between milk SCC and EC has also been estimated by Povinelli with co-authors (2005) and Norberg et al. (2006). The correlation between milk yield and milk EC in our study was slightly negative $(r=-0.168, p<0.001)$. Nielen et al. (1993) state that a rise of $1 \mathrm{mS} \mathrm{cm}^{-1}$ of the mean EC causes a decline of $0.88 \mathrm{~kg}$ a day in milk production, the correlation between mean EC and SCC being 0.32.

The study results show that the higher RNB during pasturable period had no positive effect on milk yield as SCC increased during that period and it had a negative correlation with milk yield. Analysis of literature data (Windig et al., 2005; Kul, Erdem, 2008) reveals that the level of SCC in milk has a direct correlation with udder health and a marked effect on milk production. The average EC in our study met zootechnical standards. During the pasturable period of the experiment, milk EC was 3.6\% higher than during the stall period in all lactations $(p<0.001)$. The correlation between milk SCC and EC was positive $(r=0.379, p<0.001)$, as also reported in other studies (Bansal et al., 2005).

\section{Conclusions}

1. Both during pasturable and stall periods the cows were given balanced diets. During pasturable period the diet contained $5.55 \%$ more crude protein, $0.56 \%$ more usable crude protein, ruminal N-balance (RNB) was 1.85 times higher than that in stall period diet.

2. Electrical conductivity (EC) of milk in our experiment met zootechnical standards. The highest EC of milk was observed during May-August and reached $5.02-5.11 \mathrm{mS} \mathrm{cm}^{-1}$. The average EC during pasturable period was $3.6 \%$ higher than that during stall period in all lactations $(p<0.001)$.

3. Daily milk yield during pasturable period was in average $1.4 \%$ lower compared to that during stall period $(p<0.001)$, somatic cell count (SCC) $-7.9 \%$ higher $(p<$ $0.001)$. The higher cows' RNB during pasturable period had no positive effect on milk yield as SCC increased during that period.

4. The experiment showed that the correlation between milk yield and EC was slightly negative both during pasturable $(r=-0.124)$ and stall $(r=-0.226)$ periods; however, the correlation coefficients were highly significant $(p<0.001)$.

5 . The EC of milk had a statistically significant correlation with SCC both during pasturable ( $r=0.356$, $p<0.001)$ and stall $(r=0.403, p<0.001)$ periods. SCC was lower than 200 thousand $\mathrm{ml}^{-1}$ in the milk samples with $\mathrm{EC}$ in the range of 4.6 to $5.8 \mathrm{mS} \mathrm{cm}^{-1}$.

6 . The EC of milk could provide an alternative way for early diagnosis of mastitis in dairy cows.

Received 01102012

Accepted 24092013

\section{References}

Bansal B. K., Hamann J., Grabowski N. T., Singh K. B. 2005. Variation in the composition of selected milk fraction samples from healthy and mastitic quarters, and its significance for mastitis diagnosis. Journal of Dairy Research. 72: 144-152 http://dx.doi.org/10.1017/S0022029905000798

de Mol R. M., Ouweltjes W. 2001. Detection model for mastitis in cows milked in an automatic milking system. Preventive Veterinary Medicine, 49 (1-2): 71-82 http://dx.doi.org/10.1016/S0167-5877(01)00176-3

Green M. J., Bradley A. J., Newton H., Browne W. J. 2006. Seasonal variation of bulk milk somatic cell counts in UK dairy herds: investigations of the summer rise. Preventive Veterinary Medicine. 74: 293-308

http://dx.doi.org/10.1016/j.prevetmed.2005.12.005

Hamann J., Gyodi P. 2000. Somatic cells and electrical conductivity in relation to milking frequency. Milchwissenschaft - Milk Science International, 55: 303-307

Hamann J., Zecconi A. 1998. Evaluation of the electrical conductivity of milk as a mastitis indicator. Bulletin of the International Dairy Federation, 334: 5-22

Hillerton J. E., Walton A. W. 1991. Identification of subclinical mastitis with a hand-held electrical conductivity meter. Veterinary Record, 128: 513-515 http://dx.doi.org/10.1136/vr.128.22.513

Jatkauskas J., Vrotniakienè V. 2011. The effects of silage inoculants on the fermentation and aerobic stability of legume-grass silage. Zemdirbyste-Agriculture, 98 (4): $367-374$

Juozaitienė V., Žakas A. 2002. Influence of heritability on Black-and-white cows milk quality according to somatic cells count. Veterinarija ir zootechnika, 17 (39): 72-74 (in Lithuanian)

Juozaitienè V., Juozaitis A., Žakas A. 2004. Relationship of somatic cell count with milk yield and composition in the herds of Black-and-White cattle. Medycyna Veterynaryjna, 60 (7): 701-704

Juozaitienè V., Šlapkauskaitė J., Tušas S., Brazauskas A., Japertiené R. 2010. Electrical conductivity changes of milk during milking phase with cows productivity and somatic cells count. Veterinarija ir zootechnika, 51 (73): 23-29 (in Lithuanian)

Klimienė I., Mockeliūnas R., Butrimaitè-Ambrozevičienè Č., Sakalauskienè R. 2005. The distribution of dairy cow mastitis in Lithuania. Veterinarija ir zootechnika, 31 (53): 67-76 (in Lithuanian)

Kondrotaitè D., Musayeva K., Želvytè R., Juozaitienė V., Mockevičienè I., Sederevičius A. 2013. Investigations of the dependence between somatic cell count and inhibitory substances in cow milk during pasturable period. Veterinarija ir zootechnika, 61 (83): 44-47 (in Lithuanian)

Kul E., Erdem H. 2008. Relationships between somatic cell count and udder traits in Jersey cows. Journal of Applied Animal Research. 34: 101-104 http://dx.doi.org/10.1080/09712119.2008.9706949

Mikulionienè S., Stankevičius R. 2002. Research data on the nutrients in the silage, digestibility and energetic feed value. Proceedings of international workshop Grass preservation - good practice and new knowledge. Kaunas, Lithuania, p. 49-56 (in Lithuanian)

Mockevičienè I., Želvytė R., Laugalis J., Sederevičius A., Makauskas S. 2008. The impact of different feeding technologies on feed intake, milk production and cost. Veterinarija ir zootechnika, 43 (65): 68-72 (in Lithuanian)

Moussaoui F., Vangroenweghe F., Haddadi K., Le Roux Y., Laurent F., Duchateau L., Burvenich C. 2004. Proteolysis in milk during experimental Escherichia coli mastitis. Journal of Dairy Science. 87: 2923-2931 http://dx.doi.org/10.3168/jds.S0022-0302(04)73423-2 
Musser J. M., Anderson K. L., Caballero M., Amaya D., Maroto-Puga J. 1998. Evaluation of a hand-held electrical conductivity meter for detection of subclinical mastitis in cattle. American Journal of Veterinary Research, 59 (9): 1087-1091

Nielen M., Schukken Y., van de Broek J., Brand A. 1993. Relations between on-line electrical conductivity and daily milk production on a low somatic cell count farm. Journal of Dairy Science. 76: 2589-2596 http://dx.doi.org/10.3168/jds.S0022-0302(93)77593-1

Norberg E. 2005. Electrical conductivity of milk as a phenotypic and genetic indicator of bovine mastitis: a review. Livestock Production Science. 96: 129-139 http://dx.doi.org/10.1016/j.livprodsci.2004.12.014

Norberg E., Hogeveen H., Korsgaard I. R., Friggens N. C., Sloth K. H. M. N., Løvendahl P. 2004. Electrical conductivity of milk: ability to predict mastitis status. Journal of Dairy Science. 87: 1099-1107 http://dx.doi.org/10.3168/jds.S0022-0302(04)73256-7

Norberg E., Rogers G. W., Ødegård J., Cooper J. B., Madsen P. 2006. Short communication: genetic correlation between test-day electrical conductivity of milk and mastitis. Journal of Dairy Science, 89: 779-781 http://dx.doi.org/10.3168/jds.S0022-0302(06)72139-7
Povinelli M., Gallo L., Carnier P., Marcomin D., Dal Zotto R., Cassandro M. 2005. Genetic aspects of milk electrical conductivity in Italian Brown cattle. Italian Journal of Animal Science, 4: 169-171

Riekerink R. G. M. O., Barkema H. W., Stryhn H. 2007. The effect of season on somatic cell count and the incidente of clinical mastitis. Journal of Dairy Science, 90: 1704-1715 http://dx.doi.org/10.3168/jds.2006-567

Seegers H., Fourichon C., Beaudeau F. 2003. Production effects related to mastitis and mastitis economics in dairy cattle herds. Veterinary Research, 24: 475-491

http://dx.doi.org/10.1051/vetres:2003027

Špakauskas V., Klimienė I., Matusevičius A. 2006. A comparison of indirect methods for diagnosis of subclinical mastitis in lactating dairy cows. Veterinarski Arhiv, 76 (2): 101-109

von Lengerken J. 2004. Qualität und Qualitätskontrolle bei Futtermitteln. Frankfurt am Main, Germany, p. 36-71 (in German)

Weiss J., Pabst W., Strack K. E., Granz S. 2005. Tierproduktion. Stuttgart, Germany, p. 282-330 (in German)

Windig J. J., Calus M. P. L., De Jong G., Veerkamp R. F. 2005. The association between somatic cell count patterns and milk production prior to mastitis. Livestock Production Science, 96: 291-299 http://dx.doi.org/10.1016/j.livprodsci.2005.02.009

ISSN 1392-3196 / e-ISSN 2335-8947

Zemdirbyste-Agriculture, vol. 100, No. 4 (2013), p. 363-368

DOI $10.13080 / \mathrm{z}-\mathrm{a} .2013 .100 .046$

\title{
Karvių ganyklinio ir tvartinio laikotarpių racionų ịtaka pieno elektriniam laidumui
}

\author{
A. Brazauskas, A. Juozaitis, R. Stankevičius, V. Juozaitienė, V. Žilaitis \\ Lietuvos sveikatos mokslų universiteto Veterinarijos akademija
}

\section{Santrauka}

Tyrimo tikslas - ištirti karvių raciono įtaką pieno elektriniam laidumui (EL) ganykliniu bei tvartiniu laikotarpiais ir ịvertinti EL ryšį su karvių produktyvumu bei pieno somatinių ląstelių skaičiumi (SLS). Automatizuota savanoriško melžimo sistema „DeLaval VMS“ („DeLaval“, Švedija) 2009-2013 m. buvo ištirta 421 karvè, kurios visus metus buvo laikomos tvartuose nepririštos. Tvartiniu ir ganykliniu laikotarpiais karvès šertos ūkyje pagamintais žoliniais silosuotais pašarais, ganykliniu laikotarpiu papildomai buvo duodama miglinių ir pupinių žolių mišinio. Duomenų masyvą sudarè 462582 ịrašai. Vidutinis tirtų karvių pieno EL $\left(4,92 \pm 0,001 \mathrm{mS} \mathrm{cm}^{-1}\right)$ atitiko zootechninę normą. Tyrimo laikotarpiu karvių vidutinis primilžis buvo $25,12 \pm 0,020 \mathrm{~kg}$ pieno per parą, o pieno SLS $-188,95 \pm 1,032$ tūkst. $\mathrm{ml}^{-1}$. Ganykliniu laikotarpiu karvių pieno primilžis per parą buvo vidutiniškai 1,4 \% mažesnis, o SLS - 7,9 $\%(p<0,001)$ didesnis nei tvartiniu laikotarpiu. Tirtų karvių visų laktacijų pieno EL vidurkis buvo vidutiniškai $3,6 \%$ didesnis $(p<0,001)$ ganykliniu laikotarpiu nei tvartiniu. Geresnis karvių raciono ruminalinis azoto balansas $(23,03 \mathrm{~g})$ ganykliniu laikotarpiu neturejo teigiamos įtakos karvių produktyvumui, nes šiuo laikotarpiu pieno SLS buvo didesnis. Koreliacija tarp pieno kiekio ir jo EL ganykliniu bei tvartiniu laikotarpiais buvo neigiama $(r=$ $-0,124-0,226, p<0,001)$. Pieno SLS neviršijo 200 tūkst. $\mathrm{ml}^{-1}$ mėginiuose, kuriuose EL svyravo nuo 4,6 iki 5,8 $\mathrm{mS} \mathrm{cm}{ }^{-1}$. Didejant pieno EL, pieno SLS esmingai $(p<0,001)$ didejo ir ganykliniu, ir tvartiniu laikotarpiais $(r=$ $0,356-0,403)$, todèl galima teigti, kad šis rodiklis gali būti naudojamas mastitui prognozuoti.

Reikšminiai žodžiai: koreliacija, pašarai, produktyvumas, somatinių ląstelių skaičius. 